\title{
Computed Tomography in Staging of Patients with Melanoma Metastatic to the Regional Nodes
}

\author{
Timothy M. Johnson, MD, Darrell J. Fader, MD, Alfred E. Chang, MD, Alan Yahanda, MD, \\ John W. Smith II, MD, K. Renee Hamlet, MD, and Vernon K. Sondak, MD
}

\begin{abstract}
Background: This study addresses the yield and clinical impact of computed tomography (CT) imaging in otherwise asymptomatic patients with stage III melanoma metastatic to the regional nodes.

Methods: The database from the University of Michigan Mutlidisciplinary Melanoma Clinic was reviewed and identified 127 asymptomatic patients with stage III melanoma (regional nodal disease) who received CT scans of the head, chest, abdomen, and/or pelvis. Scans were confirmed as true positive, false positive, and normal.

Results: Four hundred twenty-six head and body CT scans were performed the time of presentation of stage III disease. Twenty patients had a true-positive CT scan revealing unsuspected metastases. Fifteen patients had abnormal CT scans subsequently shown to be a benign process or second malignancy. The incidence of true-positive CT scans was not different between the groups of patients who had clinically apparent versus occult nodal disease. There was a significantly higher incidence of abdominal and pelvic metastatic sites identified by CT scan in patients with inguinal nodal disease compared with axillary or head and neck node-positive patients.

Conclusions: The yield of detection of unsuspected metastases by CT scans in asymptomatic patients with stage III melanoma was not insignificant. Because patients with resected stage III disease are recommended to have adjuvant interferon- $\alpha$ for 1 year, CT staging plays an important role in identifying appropriate candidates for treatment. The toxicity of interferon- $\alpha$ therapy is not insignificant. The value of routine CT in asymptomatic patients with nodal metastasis deserves further prospective study.
\end{abstract}

Key Words: Computed tomography staging: stage III melanoma.

The prognosis of patients with melanoma who present with lymph node metastases (AJCC clinical stage III: any $\mathrm{T}, \mathrm{N} 1$ or $\mathrm{N} 2, \mathrm{M} 0$ ) is relatively poor, suggesting that most patients who undergo lymphadenectomy for stage III disease have occult distant metastases at the time of initial diagnosis (1). Based on several reported series, the 5 -year survival rate for patients with stage III melanoma after lymphadenectomy ranges from 13 to $45 \%$, with an average of $34 \%$ (2-6). Regardless of the specific site, regional lymphadenectomy is a morbid procedure-

Received April 25, 1996; accepted September 16, 1996.

From the Departments of Dermatology (T.M.J., D.J.F., K.R.H.), Surgery (A.E.C., A.Y., V.K.S.), and Medicine (J.W.S.), University of Michigan Medical Center, and Univeristy of Michigan Comprehensive Cancer Center, Ann Arbor, Michigan, USA.

Address correspondence and reprint requests to Dr. Timothy $M$ Johnson, Department of Dermatology, Melanoma Clinic, University of Michigan Medical Center, Ann Arbor, MI 48109-0314, USA. associated with significant costs to patients and to society - that fails to cure the majority of individuals with nodal involvement $(6,7)$. Any technique capable of identifying patients with stage III disease with clinically unsuspected distant melanoma metastasis, often obviating the need for lymphadenectomy and/or relatively toxic adjuvant interferon- $\alpha$ therapy, would be likely to have significant clinical value.

Melanoma can metastasize to any organ. The most common sites of metastases are to skin, subcutaneous tissue, and lymph nodes, followed by visceral organs. Common visceral sites of metastases, in order of decreasing frequency, are lung, liver, brain, bone, and gastrointestinal tract $(8-10)$. Cutaneous and subcutaneous metastases, as well as spread to lymphatic basins amenable to palpation (e.g., neck, axilla, and groin), can be readily detected by physical examination, but involvement of mediastinal, intraabdominal, and pelvic nodes cannot. 
Likewise, most visceral metastases are initially asymptomatic and not detectable on physical examination. Elevation of the serum lactate dehydrogenase (LDH) level is generally thought to be the most sensitive serum marker of melanoma metastases, particularly to the liver, but is notorious for being of low sensitivity and specificity. Chest radiography will detect most pulmonary metastases $>1-2 \mathrm{~cm}$, but will frequently miss smaller lesions.

Computed tomography (CT) scans of the head, chest, abdomen, and pelvis offer the potential to detect most metastatic sites of melanoma that would be missed by physical examination. True-positive scans identifying unsuspected melanoma metastasis alters clinical management and is of significant clinical value. Unfortunately, these scans will also frequently identify clinically insignificant findings, such as pulmonary granulomas or hepatic cysts. These false-positive findings, moreover, often prompt significant patient anxiety as well as costly follow-up evaluations. The true value of using CT scans of the head and body in otherwise asymptomatic patients who present with lymph node metastasis is therefore a matter of significant interest in management of this disease. During an 11-year period, 127 asymptomatic patients who presented with lymph node metastases (AJCC clinical stage III disease) were evaluated in the University of Michigan Multidisciplinary Melanoma Clinic. As a part of their evaluation, patients underwent at least one CT scan of the head, chest, abdomen, or pelvis. We report the results of routine CT scanning in these patients.

\section{PATIENTS AND METHODS}

The melanoma database (from the period 1984-1995) was queried to identify 127 asymptomatic patients who had melanoma metastatic to the regional lymph nodes and who had at least one staging CT scan within 2 months of diagnosis. Patients with melanoma metastatic to the regional nodes with $\mathrm{CT}$ scans obtained beyond 2 months of diagnosis and those with signs or symptoms of distant disease before staging CT scans were excluded from chart review and analysis. The charts of these 127 patients with stage III melanoma metastatic to the regional lymph nodes seen in the University of Michigan Multidisciplinary Melanoma Clinic were retrospectively reviewed. The number and location of CT scans were obtained at the discretion of the attending physician. In total, $426 \mathrm{CT}$ scans were performed in these 127 patients of the following locations: head (99), chest (117), abdomen (121), and pelvis (89). Chest radiographs and liver function studies were not routinely ordered because most patients had CT scans of the chest and abdomen as part of the staging work-up.

CT scans were considered positive whenever an abnormality was reported by the radiologist as suspect for metastasis or whenever an indeterminate abnormality required further diagnostic evaluation or follow-up studies to define its nature. A positive scan was considered a true positive when confirmed to represent melanoma by biopsy or when subsequent follow-up documented clearcut progression in the size and/or number of lesions consistent with metastatic melanoma. A positive scan was considered a false positive when found to represent a benign process or malignant, nonmelanoma lesion by biopsy, when subsequent follow-up documented resolution or stability, or when subsequent diagnostic studies determined the lesion to be consistent with a benign process.

\section{RESULTS}

The clinical characteristics of the 127 patients with regional nodal metastases are listed in Table 1. Twentyeight patients were diagnosed with microscopic disease at elective lymph node dissection (ELND). The remaining 99 patients had palpable disease diagnosed by fineneedle aspirate, open biopsy, or therapeutic lymph node dissection. Four hundred twenty-six total scans were performed in these 127 patients ( 3.4 scans/patient). In total, $35(27 \%)$ of 127 patients had abnormal CT scans in which there were findings suspicious for metastases. Twenty patients ( $16 \%$ of total, $57 \%$ of suspect scans) were found, on subsequent workup, to have true positive findings. Fifteen patients ( $12 \%$ of total, $43 \%$ of suspect scans) were found to have false positive findings. Nineteen of the patients with true positive CT scans had them performed within 1 month of diagnosis. The remaining patient was studied within 2 months of diagnosis. Interestingly, $6(21 \%)$ of 28 patients diagnosed with microscopic disease at ELND had true positive findings, whereas $14(14 \%)$ of 99 patients with palpable disease had true positive findings. Five (18\%) of 28 patients with microscopic disease and $10(10 \%)$ of 99 patients with palpable disease had false positive findings.

In this group of 20 patients with true positive scans, significant findings for silent distant metastases were found in 6 head CT scans, 11 chest, 12 abdomen, and 4 pelvis (Table 2). Multiple positive findings were found in several scans. Of the 11 patients with true positive chest CT scans, 9 scans showed lung metastases and 4 new nodal metastases ( 1 axillary, 3 mediastinal, paratracheal, subcarinal). Confirmation of diagnosis was made by bi- 
TABLE 1. Clinical characteristics of 127 patients staged with computed tomography scanning for stage III (nodal) disease

\begin{tabular}{lr}
\hline \multicolumn{1}{c}{ Total no. of patients } & 127 \\
\hline Sex & \\
Female & 45 \\
Male & 82 \\
Age (yrs) & 52 \\
Mean & $5-83$ \\
Range & \\
Location of regional nodal disease & 62 \\
Axillary & 34 \\
Head \& neck & 28 \\
Inguinal & 4 \\
Supraclavicular & 2 \\
Epitrochlear & \\
Location of primary melanoma & 31 \\
Head \& neck & 15 \\
Upper extremity & 25 \\
Lower extremity & 42 \\
Trunk & 14 \\
Unknown & \\
Method of diagnosis before staging & 43 \\
FNA & 39 \\
Open biopsy & 28 \\
ELND & 16 \\
Open biopsy-ELND (same time) & 1 \\
Clinical mass & \\
No. of initial scans performed on patient & \\
(head/chest/abdomen or pelvis) & 66 \\
4 & 44 \\
3 & 12 \\
2 & \\
1 & \\
\hline
\end{tabular}

ELND, elective lymph node dissection.

a Three patients had two different simultaneous sites of nodal thetastasis from a primary lesion located on the trunk.

opsy in three cases and progression of disease in the remaining cases. In those 11 patients with true positive chest CT scan findings, a chest radiograph was not ordered in 5 , was negative in 3 , and was positive in 3 . Of the six true positive CT scans of the head, five showed brain metastases, and one showed a cervical spine metastasis. Confirmation of metastases was made by biopsy in two patients and progression of disease in four.

Of the 12 patients with true positive abdomen CT scans, 6 scans showed metastases to the liver, 3 to the spleen, 1 to the adrenal gland, and 6 to visceral nodes (retroperitoneal, periaortic, or mesenteric), 1 to the spine, and 2 to subcutaneous or extraperitoneal soft tissues. Diagnosis was confirmed by clear-cut progression of disease in all cases. Of the six patients with liver metastasis, serum LDH was elevated in three and normal in three. True positive abdominal $\mathrm{CT}$ scans yielded extrahepatic $(68 \%)$ metastasis more often than hepatic $(32 \%)$ metastasis. Of the four true positive CT scans of the pelvis, all showed enlarged (or abnormal) retroperitoneal or periaortic nodes. The diagnosis was similarly confirmed by progression of disease in all cases. All four patients had the primary melanoma located on the lower extremity. In summary, $6(6 \%)$ of 99 CT scans of the head, $11(9 \%)$ of 117 chest, $12(10 \%)$ of 121 abdomen, and $4(4 \%)$ of 89 pelvis demonstrated unknown distant metastases in our series (Table 3). Of note, pelvic CT scans demonstrated metastases in $4(16 \%)$ of 25 patients with the primary melanoma on the lower extremity.

Fifteen (12\%) of 127 patients had false positive CT scans that showed abnormalities considered suspect for metastases that were shown to be unrelated to melanoma by subsequent studies (Table 4). Of these, 9 abnormal CT scans of the chest were found. Four showed a lung nodule and one an axillary node that resolved or remained stable with subsequent follow-up studies. One showed a paratracheal mass thought to be thyroid, one a left breast mass confirmed to be a benign cyst by biopsy, one a precarinal node negative for metastases by biopsy, and one lytic fourth/rib lesion revealing an undiagnosed multiple myeloma by biopsy. Of the eight abnormal abdominal CT scans, five revealed benign lesions: liver cysts by biopsy in two and, based on follow-up scans in three, one a liver mass negative for melanoma after two biopsies, one adrenal adenoma by biopsy, and one consistent with a hemangioma based on follow-up scans. Two of these 15 patients had two abnormal scans (chest and abdomen) accounting for the total of 17 abnormal scans. No false positives were found by CT scans of the head and pelvis (see Table 3).

Stratification of the data with respect to location of regional disease found a higher percentage of true positive findings in patients with axillary and inguinal metastasis compared with those for head and neck (Table 5). Seven ( $25 \%$ ) of 28 patients with inguinal metastasis were found to have true positive scans most commonly of the abdomen (19\%), pelvis (15\%), and chest (13\%). Twelve $(19 \%)$ of 64 patients with axillary metastasis were found to have true positive scans, most commonly of the chest $(15 \%)$, abdomen $(12 \%)$, and head $(9 \%)$. Three $(8 \%)$ of 38 head and neck and supraclavicular metastasis were found to have true positive scans, most commonly of the chest $(5 \%)$.

\section{DISCUSSION}

Numerous investigators have shown that $\mathrm{CT}$ scanning of the head and body and other diagnostic radionuclide testing is neither useful nor cost effective in detecting silent metastases in patients with localized (AJCC stage I and II) melanoma $(11,12)$. This has been our experience as well.

Khansur et al. (12) reported 54 patients with nodal metastases and 28 with local/regional recurrences. These 
TABLE 2. Computed tomography scan findings in 20 patients who presented with abnormal scans detecting silent distant metastases

\begin{tabular}{|c|c|c|c|c|}
\hline $\begin{array}{l}\mathrm{Pt} \\
\text { no. }\end{array}$ & $\begin{array}{l}\text { Location of } \\
\text { regional nodal } \\
\text { metastasis }\end{array}$ & $\begin{array}{l}\text { Microscopic } \\
\text { vs. palpable } \\
\text { disease }\end{array}$ & $\begin{array}{l}\text { Radiologic findings } \\
\text { by CT scan }\end{array}$ & Comments \\
\hline 1 & Inguinal & Palpable & $\begin{array}{l}\text { (A/P) Paraaortic, common and common external } \\
\text { iliac, obturator nodes }\end{array}$ & $\begin{array}{l}\text { Repeat (A/P) CT after } 3 \text { tho showed progressive } \\
\text { increase in size and number of nodes. Patient } \\
\text { died of widespread disease. }\end{array}$ \\
\hline 2 & $\begin{array}{l}\text { Axillary and } \\
\text { supraclavicular }\end{array}$ & Palpable & $\begin{array}{l}\text { (C) } 1.5-\mathrm{cm} \text { subclinical node and other smaller } \\
\text { nodes left axilla }\end{array}$ & $\begin{array}{l}\text { Repeat chest CT@ } 4 \text { mo showed progression in } \\
\text { size and number of left axillary nodes, pleural, } \\
\text { and chest wall metastases; DOD, initial CXR } \\
\text { negative. CXR positive at } 4 \text { mo. }\end{array}$ \\
\hline 3 & Axillary & Microscopic & $\begin{array}{l}\text { (H) Multiple brain metastases } \\
\text { (A) Multiple Iver/spleen metastases }\end{array}$ & $\begin{array}{l}\text { Patient developed widespread metastases, mental } \\
\text { status changes; DOD } 1 \text { mo after initial CTs. } \\
\text { LDH elevated. }\end{array}$ \\
\hline 4 & Inguinal & Palpable & $\begin{array}{l}\text { (A/P) Extensive paraaortic, retroperitoneal, } \\
\text { external iliac nodes }\end{array}$ & Rapid progression; DOD. \\
\hline 5 & Axillary & Microscopic & (A) Multiple lesions, $R$ lobe liver & $\begin{array}{l}\text { Repeat CT (A) 2, 4, and } 8 \text { mos; progression in } \\
\text { size and number of metastases, spleen } \\
\text { metastases. Widespread metastases in head, } \\
\text { chest, abdomen } 8 \text { mo after initial CTs. Initial } \\
\text { LDH nomal, elevated at } 1 \text { mo. }\end{array}$ \\
\hline 6 & Inguinal and axillary & Palpable & $\begin{array}{l}\text { (C) } 4 \text { small } 5 \text {-mm lung nodules, mediastinal, } \\
\text { paratracheal, subcarinal nodes } \\
\text { (P) External iliac nodes bilateral }\end{array}$ & $\begin{array}{l}\text { Repeat } \mathrm{CT}(\mathrm{C}) 1,3,5,7,9 \text { mo showed } \\
\text { progression of disease. Initial CXR negative. }\end{array}$ \\
\hline 7 & Axillary & Microscopic & $\begin{array}{l}\text { (C) Multiple bilateral pulmonary nodules, } \\
\text { subcarinal, retrocrural, gastrohepatic nodes } \\
\text { (H) Multiple 1-2-mm areas of enhancement } \\
\text { consistent with brain metastases }\end{array}$ & Biopsy of lung nodules positive for melanoma. \\
\hline 8 & Axillary & Palpable & $\begin{array}{l}\text { (A) Multiple liver, spleen, abdominal wall } \\
\text { nodules }\end{array}$ & $\begin{array}{l}\text { Repeat CT (A) after } 1 \text { mo showed rapid } \\
\text { progression of disease. LDH elevated. }\end{array}$ \\
\hline 9 & Axillary & Palpable & $\begin{array}{l}\text { (A) Extensive liver/spleen metastases, necrotic } \\
\text { peripancreatic adenopathy, multiple } \\
\text { omental/mesenteric/retroperitoneal nodules, } \\
\text { and multiple vertebral body lucencies. } \\
\text { (C) Multiple lung nodules. } \\
\text { (H) Multiple brain metastases. }\end{array}$ & $\begin{array}{l}\text { Repeat } \mathrm{CT}(\mathrm{A}, \mathrm{C}) 2 \text { and } 3 \text { mo showed progression } \\
\text { in size and number of metastases. LDH } \\
\text { elevated. Initial CXR negative. }\end{array}$ \\
\hline 10 & Axillary & Palpable & $\begin{array}{l}\text { (C) Enlarged precarinal node. } \\
\text { (A) Aortocaval, retrocrural adenopathy }\end{array}$ & $\begin{array}{l}\text { Marked progression of widespread metastatic } \\
\text { disease with increase in thoracic, abdominal, } \\
\text { retroperitoneal, and mesenteric } \\
\text { lymphadenopathy on repeat CT scans at } 10 \\
\text { months. }\end{array}$ \\
\hline 11 & Axillary & Palpable & (C) $25-50<1-1.5-\mathrm{cm}$ lung nodules & $\begin{array}{l}\text { Progression of metastatic melanoma to multiple } \\
\text { organs. Lung biopsy positive for melanoma. }\end{array}$ \\
\hline 12 & Axillary & Microscopic & (A) Multiple low-attenuation liver lesions & $\begin{array}{l}\text { Repeat CT (A) and CXR at } 3 \text { mo showed } \\
\text { progression of metastases to lung/liver. Patient } \\
\text { developed widespread melanoma metastases } \\
\text { over } 8 \text { mo. Initial LDH normal, elevated at } 7 \\
\text { mo. }\end{array}$ \\
\hline 13 & Axillary & Microscopic & $\begin{array}{l}\text { (C) Multiple lung nodules } \\
\text { (A) Paraaortic nodes } \\
\text { (H) Frontal brain metastases }\end{array}$ & $\begin{array}{l}\text { Rapid clinical and CXR progression of metastatic } \\
\text { melanoma. DOD } 6 \text { mo after stage III } \\
\text { diagnosis. Initial CXR positive. }\end{array}$ \\
\hline 14 & Inguinal & Palpable & (A) 2-cm adrenal mass & $\begin{array}{l}\text { Patient developed widespread metastases to the } \\
\text { lungs, adrenal glands, kidneys, subcutaneous } \\
\text { fat, and peritoneal cavity over } 1 \text { yr. }\end{array}$ \\
\hline 15 & Inguinal & Microscopic & (A/P) Paraaortic/refrocaval/retroaortic nodes & $\begin{array}{l}\text { Repeat MRI (A) at } 1 \text { mo showed progression of } \\
\text { disease. }\end{array}$ \\
\hline 16 & Inguinal & Palpable & $\begin{array}{l}\text { (C) Multiple lung nodules } \\
\text { (A) Multiple liver nodules, 3-4-cm soft-tissue } \\
\text { mass at the ileocecal valve }\end{array}$ & $\begin{array}{l}\text { Repeat CT (C/A) showed progression of size and } \\
\text { number of lung/liver metastases. Initial LDH } \\
\text { nomal, not repeated. Initial CXR positive. }\end{array}$ \\
\hline 17 & Head and neck & Palpable & (C) Multiple lung nodules & $\begin{array}{l}\text { Biopsy of lung nodule positive for metastic } \\
\text { melanoma. }\end{array}$ \\
\hline 18 & Axillary & Palpable & (C) Lung nodule & Biopsy positive for melanoma. \\
\hline 19 & Inguinal & Palpable & $\begin{array}{l}\text { (C) } 2 \text { small lung nodules } \\
\text { (H) Cervical spine (C2) destructive process }\end{array}$ & $\begin{array}{l}\text { Biopsy of cervical spine positive for melanoma. } \\
\text { Repeat CT at } 2 \text { mos showed progression of } \\
\text { lung metastases. Patient alive } 1.5 \mathrm{yrs} \text { after } \\
\text { diagnosis of metastases. }\end{array}$ \\
\hline 20 & Head and neck & Palpable & (H) 1.7-cm mass lesion choroid plexus & $\begin{array}{l}\text { Biopsy positive for melanoma brain metastases. } \\
\text { Patient alive with disease } 3 \text { yr after diagnosis } \\
\text { of brain metastases. }\end{array}$ \\
\hline
\end{tabular}

(H), head CT; (C), chest CT; (A), abdomen CT; (P), pelvis CT; DOD, dead of disease; LDH, lactate dehydrogenase; CXR, chest radiograph. 
TABLE 3. Stumary of computed tomography (CT) scan findings

\begin{tabular}{lccc}
\hline CT scan & Total no. & $\begin{array}{c}\text { True } \\
\text { positive }\end{array}$ & $\begin{array}{c}\text { False } \\
\text { positive }\end{array}$ \\
\hline Head & 99 & $6(6 \%)$ & 0 \\
Chest & 117 & $11(9 \%)$ & $9(8 \%)$ \\
Abdomen & 121 & $12(10 \%)$ & $8(7 \%)$ \\
Pelvis & 89 & $4(4 \%)$ & 0 \\
\hline
\end{tabular}

patients underwent some combination of the following evaluations: radionuclide brain, bone, and liver scan; CT scan of the head; and upper gastrointestinal series with small-bowel follow-through. All patients in their series had a chest radiograph, liver function tests, and serum LDH. Seven asymptomatic patients had lung metastases by chest radiography. Five abnormal radionuclide scans detected metastases in the brain (one), bone (one), gastrointestinal tract (one), and spleen (two) in asymptomatic patients with normal liver function tests. The authors did not state whether multiple metastases in the same patient were found with abnormal chest radiographs and radionuclide scans. Still, these data suggest that a chest radiograph and a battery of radionuclide scans may detect metastases in at least $10 \%$ of asymptomatic stage III patients.

Roth et al. (13) and Thomas et al. (14) reported on the value of brain, bone, and liver-spleen nuclear medicine scans in 58 and 48 patients, respectively, with stage III disease. Only one patient had an abnormal scan detecting distant metastases. There were a significant number of false positive scan results in these series. Therefore, it was concluded that radionuclide scanning was not indicated for screening of patients with stage III disease.

The value of head and body CT imaging in patients who present with nodal metastases (AJCC stage III) has been evaluated in one large series (15). Buzaid et al. (15) analyzed 89 asymptomatic patients with stage III localregional melanoma who had both a normal chest radiograph and normal serum LDH level. Sixty-six patients had purely nodal disease. The remaining 23 patients had in-transit/satellite or local recurrence with (8) or without (15) nodal disease. A total of $304 \mathrm{CT}$ scans were performed in those 89 patients in the following locations: head (57), neck (16), chest (82), abdomen (86), and pelvis (63). True positive findings were found in six patients (7\%). True positive findings were noted in one chest and five abdomen or pelvis scans. Pelvic CT scans showed metastases in 4 of $28(14 \%)$ patients with melanoma below the waist. False positive findings were found in 20 of $89(22 \%)$ patients. No CT scans of the brain showed CNS metastases, although an asymptomatic skull metastasis was found in one patient. Buzaid et al. (15) con- cluded that a CT scan of the chest adds little to the information obtained from a chest radiograph and therefore, may not be indicated. Additionally, an elevated serum LDH level may indicate metastatic disease, but the specificity and sensitivity of LDH levels were low. However, an elevated LDH level, particularly in the postoperative period, may indicate distant metastasis.

Our study group contained approximately two times the number of pure node positive patients reported by Buzaid et al. Our group was not consistently evaluated with routine chest radiographs or serum LDH levels because CT scans of the chest and abdomen were routinely performed. In the 11 patients with positive CT scans of the chest, a chest radiograph was not obtained in 5, negative in 3 , and positive in 3 . In our series, abdominal CT scans were more likely to yield nonhepatic $(68 \%)$ than hepatic (32\%) metastases. All false positive scan results were found in either the chest (9) or abdomen (8). In fact, the frequency of a false positive versus true positive scan in the chest and abdomen were about equal. Still, the false positive findings often served as a useful baseline for comparison in this high-risk group of patients with stage III melanoma. Of note, no false positive CT scans were found in the head and pelvis.

The most striking significant difference between our series and the series reported by Buzaid et al. (15) is the result of CT scanning of the head. Although Buzaid et al. reported no brain metastases and only 1 skull metastasis in 57 head CT scans, we found 5 brain metastases and 1 spinal metastasis in 99 studies. Melanoma has a clear predilection for metastases to the CNS, one of the most ominous features of the disease. Our study contained 1.4 times the number of total patients and nearly two times the number of pure node positive patients and number of CT scans of the head compared with the series by Buzaid et al. The gender, median age, and type of lymph node dissection (elective versus theraputic) were similar between the two studies.

Documentation of CNS involvement has an impact on the management of the patient, given the fact that surgical and/or medical control of melanoma outside the CNS, although usually palliative, continues to improve. Surgical resection or stereotactic radiosurgical intervention for CNS melanoma, although not curative, may increase survival in patients with little morbidity and mortality even in the presence of extracranial metastases $(16,17)$. Additionally, the presence of CNS disease usually precludes patient eligibility for treatments such as interleukin-2, or innovative protocols such as gene therapy, adoptive immunotherapy, and gene-modified adoptive immunotherapy $(7,18-22)$.

Interestingly, our series demonstrated a similar true 
TABLE 4. Radiologic findings in 15 patients who presented with abnormal scans at the time of diagnosis found to be unrelated to melanoma

\begin{tabular}{|c|c|c|c|c|}
\hline $\begin{array}{l}\text { Pt } \\
\text { no. }\end{array}$ & $\begin{array}{l}\text { Location of } \\
\text { regional nodal } \\
\text { metastasis }\end{array}$ & $\begin{array}{l}\text { Microscopic } \\
\text { vs. palpable } \\
\text { disease }\end{array}$ & $\begin{array}{l}\text { Radiologic findings } \\
\text { by CT scan }\end{array}$ & Comments \\
\hline 1 & Head and neck & Microscopic & (C) Lung nodule & Repeat $\mathrm{CT}(\mathrm{C})$ at $3 \mathrm{mo}, \mathrm{CXR}$ at 5 yrs unchanged. \\
\hline 2 & Head and neck & Palpable & (C) 2 small lung nodules $R$ L lobe & Repeat $C X R$ negative at $1 \mathrm{yr}$ \\
\hline 3 & Axillary & Palpable & (A) Adrenal mass & Biopsy-adenoma. \\
\hline 4 & Axillary & Palpable & (A) Liver mass & $\begin{array}{l}\text { Repeat MRI consistent with benign cysts. Repeat } \\
\text { CT (A) at } 5 \text { mo unchanged. }\end{array}$ \\
\hline 5 & Axillary & Microscopic & (C) Axillary node & Repeat CT (C) at 2 mos: node resolved. \\
\hline 6 & Axillary & Palpable & (C) Precarinal node & Biopsy negative for melanoma. \\
\hline 7 & Inguinal & Microscopic & (A) Liver nodule & Biopsy $\times 2$ negative for melanoma. \\
\hline 8 & Inguinal & Palpable & (C) Breast density & bjopsy showed benign cyst. \\
\hline 9 & Head and neck & Microscopic & (C) Fourth rib lesion & Biopsy positive for multiple myeloma. \\
\hline 10 & Axillary & Microscopic & $\begin{array}{l}\text { (C) Paratracheal mass } \mathrm{C} / \mathrm{W} \\
\text { retrostemal thyroid } \\
\text { (A) Liver mass }\end{array}$ & $\begin{array}{l}\text { Repeat } \mathrm{CT}(\mathrm{C} / \mathrm{A}) \text { at } 3 \text { and } 12 \text { mo unchanged; liver } \\
\text { mass } \mathrm{C} \text { W hemangioma. }\end{array}$ \\
\hline 11 & Axillary & Palpable & (A) Liver lesion & Biopsy showed benign cyst. \\
\hline 12 & Inguinal & Palpable & (A) Tiny liver lesion & Repeat $\mathrm{CT}(\mathrm{A})$ at 6 and 24 mo unchanged. \\
\hline 13 & Axillary & Palpable & $\begin{array}{l}\text { (C) 4-mm lung nodule } \\
\text { (A) }<1-\mathrm{cm} \text { liver lesion }\end{array}$ & $\begin{array}{l}\text { Repeat } \mathrm{CT}(\mathrm{C} / \mathrm{A}) \text { at } 3 \text { mo unchanged. Liver lesion } \\
\text { consistent with benign cyst. }\end{array}$ \\
\hline 14 & Head and neck & Palpable & (A) $4-\mathrm{cm}$ liver mass & Biopsy showed benign cyst. \\
\hline 15 & Inguinal & Palpable & $\begin{array}{l}\text { (C) Single } 7 \times 5 \text {-mm nodule } R \\
\text { perihilar region }\end{array}$ & Repeat CT (C) at 6 mo, nodule resolved. \\
\hline
\end{tabular}

MRI, magnetic resonance imaging. For other abbreviations, see Table 2.

positive rate for patients with microscopic disease diagnosed by ELND versus patients with palpable disease. This finding may reflect our close follow-up and teaching of the importance of self lymph node examination to the patient resulting in early detection of palpable nodal disease. The similar number of true positive scans in the patients with microscopic disease and early palpable disease is consistent with two prospective randomized trials reporting no improvement in survival in patients treated

TABLE 5. Computed tomography (CT) scan findings with respect to location of regional metastasis

\begin{tabular}{|c|c|c|c|}
\hline $\begin{array}{l}\text { Location of } \\
\text { regional nodal } \\
\text { metastasis }\end{array}$ & $\begin{array}{l}\text { No. of } \\
\text { patients }\end{array}$ & $\begin{array}{l}\text { No. of } \\
\text { patients with } \\
\text { true positive } \\
\text { scans }\end{array}$ & $\begin{array}{l}\text { Location of } \\
\text { positive CT scans } \\
\text { and percentage of } \\
\text { total scans } \\
\text { positive for } \\
\text { each location }\end{array}$ \\
\hline Axilla/epitrochlear & 64 & $12(19 \%)$ & $\begin{array}{l}4 \text { Head }(9 \%) \\
8 \text { Chest }(15 \%) \\
7 \text { Abdomen }(12 \%) \\
1 \text { Pelvis }(3 \%)\end{array}$ \\
\hline Inguinal & 28 & $7(25 \%)$ & $\begin{array}{l}1 \text { Head }(6 \%) \\
3 \text { Chest }(13 \%) \\
5 \text { Abdomen }(19 \%) \\
4 \text { Pelvis }(15 \%)\end{array}$ \\
\hline $\begin{array}{l}\text { Head/neck } \\
\text { Supraclavicular }\end{array}$ & 38 & $3(8 \%)$ & $\begin{array}{l}1 \text { Head }(3 \%) \\
2 \text { Chest }(5 \%) \\
0 \text { Abdomen }(0 \%) \\
0 \text { Pelvis }(0 \%)\end{array}$ \\
\hline
\end{tabular}

${ }^{a}$ Three patients had more than one location of metastasis simultaneously with the primary lesion located on the trunk in an area of multiple primary nodal drainage areas. with ELND versus a watch and wait approach, with therapeutic lymphadenectomy performed only when there are signs of nodal metastasis $(23,24)$. With the recent data reporting the modest efficacy of adjuvant therapy with interferon- $\alpha$ for patients with stage III melanoma, the new technique of lymphatic mapping and sentinal node biopsy has gained popularity and has replaced ELND for nodal staging (25-29). In this setting, the finding of stage IV disease documented with CT scans would alter clinical management by both altering systemic therapy and avoiding a relatively toxic regimen of adjuvant interferon- $\alpha(30)$, and reserving palliative lymphadenectomy only for those patients who are symptomatic from their nodal disease.

On the basis of the results from our series, the following conclusions can be drawn regarding head and body CT scanning for patients with metastatic melanoma to the regional nodes. First, false positive findings are almost as common as true positive findings. Therefore, follow-up studies noting obvious progression of disease or preferably a tissue diagnosis are often necessary to confirm the presence of metastatic melanoma. Second, CT scanning or magnetic resonance imaging of the head rarely detects brain metastases. Although the yield is low, the impact of positive findings may be significant. Third, CT scanning of the pelvis is indicated only for patients in whom the primary melanoma lymphatics drain to the pelvic nodal basin. Fourth, abdominal CT scanning is recommended and is more likely to demon- 
strate extrahepatic metastatic disease, which may not be detected by an elevated serum LDH level. Of note, three $(50 \%)$ of six patients with liver metastasis had a concurrent normal LDH level. Finally, a small number of pulmonary metastases may be detected by chest CT despite a negative chest radiograph. Our retrospective analysis does not permit a definitive conclusion to be drawn regarding the utility of chest radiograph versus chest $\mathrm{CT}$ scanning in patients with stage III melanoma, because a chest radiograph was not routinely obtained. However, of note, $3(27 \%)$ of 11 patients with a true positive CT scan of the chest had a concurrent normal chest radiograph.

In conclusion, routine head and body CT scanning in asymptomatic patients with melanoma metastatic to the regional nodes infrequently identifies unsuspected metastatic disease. However, unsuspected metastatic disease may alter the subsequent clinical management in these patients. In our cost-conscious age, the benefit of head and body staging CT must be weighed against the cost. Based on our data, prospective evaluation and cost/ outcome analyses of routine head and body staging CT scanning for patients with melanoma metastatic to the regional nodes deserves further study.

\section{REFERENCES}

1. Balch CM, Cascinelli N, Drzewiecki KT, Eldh J, MacKie RM, McCarthy WH, et al. A comparison of prognostic factors worldwide. In: Balch CM, Houghton AN, Milton GW, Sober AJ, Soong S, eds. Cutaneous melanoma. Philadelphia: JB Lippincott, 1992: $188-99$.

2. Cohen MH, Ketcham AS, Felix EL, Li SH, Tomaszewski MM, Costa I, Rabson AS, et al. Prognostic factors in patients undergoing lymphadenectomy for malignant melanoma. Ann Surg 1977; $186: 635-42$.

3. Callery C, Cochran AJ, Roe DJ, Rees W, Nathanson SD, Benedetti JK, Elashoff RM, et al. Factors prognostic for survival in patients with malignant melanoma spread to the regional lymph nodes. Ann Surg 1982;196:69-75.

4. Calabro A, Singletary SE, Balch CM. Patterns of relapse in 1001 consecutive patients with melanoma nodal metastases. Arch Surg 1989;124:1051-5.

5. Bevilacqua RG, Coit DG, Rogatko A, Younes RN, Breenan MF. Axillary dissection in melanoma: prognostic variables in nodepositive patients. Ann Surg 1990;212:125-31.

6. Malignant melanoma of the skin (excluding eyelid). In: Beahrs $\mathrm{OH}$, Henson DE, Hutter RVP, Kennedy BJ, eds. American Joint Committee on Cancer Manual for Staging of Cancer. Philadelphia: JB Lippincott, 1992:143-8.

7. Johnson TM, Smith JW II, Nelson BR, Chang AE. Current therapy for cutaneous melanoma. $J$ Am Acad Dermatol 1995;32;689-707.

8. Balch CM, Soong S, Murad TM, Smith JW, Maddox WA, Durant JR. A multifactorial analysis of melanoma. IV. Prognostic factors in 200 melanoma patients with distant metastases (stage III). J Clin Oncol 1983;1:126-34.

9. Amer MH, AI-Sarraf M, Vaitkevicius VK. Clinical presentation, natural history and prognostic factors in advanced malignant melanoma. Surg Gynecol Obstet 1979;149:687-92.

10. Stehlin JS, Hills WJ, Rufino C. Disseminated melanoma: biologic behavior and treatment. Arch Surg 1967:94:495-501.
11. Buzaid AC, Sandler AB, Mani S, Curtis AM, Poo WJ, Bolongnia $\mathrm{JL}$, Ariyan S, et al. Role of computed tomography in the staging of primary melanoma. J Clin Oncol 1993;11:638-43.

12. Khansur T, Sanders J, Das SK. Evaluation of staging work-up in malignant melanoma. Arch Surg 1989;124:847-9.

13. Roth JA, Eilber FR, Bennet LR, Morton DL. Radionuclide photoscanning. Usefulness in preoperative evaluation in melanoma patients. Arch Surg 1975;110:1211-12.

14. Thomas JH, Panousopoulous D, Liesmann GE, Jewell WR, Preston DF. Scintiscans in the evaluation of patients with malignant melanoma. Surg Gynecol Obstet 1979;149:574-76.

15. Buzaid AC, Tinoco L, Ross MI, Legha SS, Benjamine RS. Role of computed tomography in the staging of patients with local-regional metastases of melanoma. $J$ Clin Oncol 1995;13:2104-8.

16. Galicich JH, Sundaresan N, Arbit E, Passe S. Surgical treatment of single brain metastasis: factors associated with survival. Cancer $1980 ; 45: 381-6$

17. Brega K, Robinson WA, Winston $K$, Wittenberg W. Surgical treatment of brain metastases in malignant melanoma. Cancer 1990; 66:2105-10.

18. Rosenberg SA, Yang JC, Topalian SL, Schwartzentruber DJ, Weber JS, Parkinson DR, Seipp CA, et al. Treatment of 283 consecutive patients with metastatic melanoma or renal cell cancer using high-dose bolus interleukin-2. JAMA 1994;271:907-13.

19. Rosenberg SA: Aebersold P, Conetta K, Kasid A, Morgan RA, Moen RA, Moen R, et al, Gene transfer into humans; immunotherapy of patients with advanced melanoma, using tumorinfiltrating lymphocytes modified by retroviral gene transduction. N Engl J Med 1990;323:570-8.

20. Pockaj BA, Sherry RM, Wei JP, Yannelli JR, Carter CS, Letiman SF, Carasquillo JA, et al. Localization of 111 indium-labeled tumor infiltrating lymphocytes to tumor in patients receiving adoptive immunotherapy. Cancer 1994;73:1731-7.

21. Nabel GJ, Nabel EG, Yang ZY, Fox BA, Plautz GE, Gao X, Huang $\mathrm{L}$, et al. Direct gene transfer with DNA-liposome complexes in melanoma: expression, biologic activity, and lack of toxicity in humans. Proc Natl Acad Sci U S A 1993;90:11307-11.

22. Vile RG, Hart IR. Use of tissue-specific expression of the herpes simplex virus thymidine kinase gene to inhibit growth of established murine melanomas following direct intratumoral injection of DNA. Cancer Res 1993;53:3860-4.

23. Veronesi U, Adams J, Bandiera DC, Brennhovd O, Caceres E, Cascinelli $N$, Claudio $F$, et al. Delayed regional lymph node dissection in stage I malignant melanoma of the skin of the lower extremities. Cancer 1982;49:2420-30.

24. Sim FH, Taylor WF, Pritchard DJ, Soule EH. Lymphadenectomy in the management of stage I malignant melanoma: a prospective randomized study. Mayo Clin Proc 1986;61:697-705.

25. Morton DL, Wen DR, Wong JH, Economou JS, Cagle LA, Storm FK, Foshag LJ, et al. Technical details of intraoperative lymphatic mapping for early stage melanoma. Arch Surg 1992;127:392-9.

26. Morton DL, Wen DR, Foshag LJ, Essner R, Cochran A. Intraoperative lymphatic mapping and selective cervical lymphadenectomy for early-stage melanomas of the head and neck. I Clin Oncol 1993;11:1751-6.

27. Krag DN, Meijer SJ, Weaver DL, Loggie BW, Harlow SP, Tanabe $\mathrm{KK}$, Laughlin $\mathrm{EH}$, et al. Minimal-access surgery for staging of malignant melanoma. Arch Surg 1995;130:654 8.

28. Ross MI, Reintgen D, Balch CM. Selective Iymphadenectomy: emerging role for lymphatic mapping and sentinel node biopsy in the management of early stage melanoma. Semin Surg Oncol 1993; 9:219-23.

29. Reintgen D, Cruse CW, Wells K, Berman C, Fenske N, Glass F, Schroer K, et al. The orderly progression of melanoma nodal metastases. Ann Surg 1994;220:759-67.

30. Kirkwood JM, Strawderman MH, Ennstoff MS, Smith TJ, Borden $\mathrm{EC}$, Blum RH. Interferon alfa-2b adjuvant therapy of high-risk resected cutaneous melanoma: the Eastern Cooperative Oncology Group Trial EST 1684. I Clin Oncol 1996;14:7-17. 